\title{
Molecular Characterization of pssCDE Genes of $R$ hizobium leguminosarum bv. trifolii strain TA1: pss $D$ Mutant Is Affected in Exopolysaccharide Synthesis and Endocytosis of Bacteria
}

\author{
Jaroslaw Król,, Jerzy Wielbo, ${ }^{1}$ Andrzej Mazur, ${ }^{1}$ Joanna Kopcinska, ${ }^{2}$ Barbara Lotocka, ${ }^{2}$ \\ Wladyslaw Golinowski, ${ }^{2}$ and Anna Skorupska ${ }^{1}$ \\ ${ }^{1}$ Department of General Microbiology, M. Curie-Sklodowska University, Akademicka 19, 20-033 Lublin, \\ Poland; ${ }^{2}$ Department of Botany, Faculty of Agriculture, Warsaw Agricultural University, Rakowiecka \\ 26/30, 02-528 Warsaw, Poland \\ Accepted 15 July 1998.
}

\begin{abstract}
We have identified the three genes pssCDE in Rhizobium leguminosarum bv. trifolii TA1. Even though they were almost identical to earlier identified pss $C D E$ genes of $R$. leguminosarum, they differed in gene lengths and gene overlaps. The predicted gene products of pss $C D E$ genes shared significant homology to prokaryotic glycosyl transferases involved in exopolysaccharide synthesis. The Tn5 insertion in $p s s D$ created the nonmucoid mutant that induced non-nitrogen-fixing nodules. The microscopic analysis of the nodules, induced on Trifolium pratense by the pssD133 mutant, showed abnormally enlarged infection threads densely packed with bacteria, which were released from the infection threads in an unusual way. The symbiosomes were observed very rarely and the nodule remained almost empty. Symbiotic phenotype of the pss $D 133$ suggested a correlation between this mutation and defective endocytosis of bacteria into nodule cells.
\end{abstract}

Acidic exopolysaccharide (EPS) synthesized by rhizobia is important for the induction of nitrogen-fixing nodules on leguminous plants such as alfalfa, clover, or pea, which form indeterminate type of nodules (reviewed in Diebold and Noel 1989; Leigh and Walker 1994; Noel 1992). Mutants of R. leguminosarum bvs. trifolii and viciae deficient in EPS synthesis $\left(\mathrm{Exo}^{-}\right)$formed nodules that were partially infected, but did not fix nitrogen (Chen et al. 1985; Deryło et al. 1986; Rolfe et al. 1996; Skorupska et al. 1995; van Workum et al. 1995, 1997). Nodules induced on clover by $\mathrm{Exo}^{-}$mutants of $R$. leguminosarum bv. trifolii were poorly developed, but infection threads occurred and bacteria were released into plant cells (Białek et al. 1995; Skorupska et al. 1995; Rolfe et al. 1996). The mutated bacteria differentiated into bacteroids, which

Corresponding author: Anna Skorupska

E-mail: genet@biotop.umcs.lublin.pl

Nucleotide and/or amino acid sequence data are to be found at GenBank or EMBL as accession no. AF014054. were deviated in ultrastructure, prematurely degenerated, and did not fix nitrogen (Białek et al. 1995). Some Exo- mutants of $R$. leguminosarum bv. trifolii induced noninfected nodules that contained neither infection threads nor bacteroids (Skorupska et al. 1995).

Whereas the genetic control of succinoglycan (EPSI) and galactoglucan (EPSII) in Sinorhizobium meliloti is well known (Becker et al. 1993a, 1993b, 1997; Buendia et al. 1991; Glucksmann et al. 1993a, 1993b; Müller et al. 1993; Reuber and Walker 1993), relatively little is known of the genetic control of synthesis and regulation of EPS in $R$. leguminosarum biovars. Until the present time, the pssA gene probably encoding the first glycosyl transferase in EPS synthesis was characterized in R. leguminosarum (Borthakur et al. 1986, 1988; Ivashina et al. 1994; van Workum et al. 1997). Three other genes, pssCDE, involved in EPS biosynthesis in $R$. leguminosarum bv. trifolii 5599 were identified (van Workum et al. 1997). Recently, the biochemical function of $p s s D E$ genes of $R$. leguminosarum was identified as glucuronosyl-( $\beta 1 \rightarrow 4)$ glucosyl transferase (Pollock et al. 1998). The pssC gene was characterized as coding for a glucuronosyl- $(\beta 1 \rightarrow 4)$-glucuronosyl transferase (Pollock et al. 1998). The exoB gene encoding the UDP-glucose 4-epimerase was identified in $R$. leguminosarum bv. trifolii (Sanchez-Andujar et al. 1997). Previously, the $p s i$ and psr genes, located on pSym plasmid of $R$. leguminosarum bv. phaseoli, which are engaged in the regulation of EPS biosynthesis, have been described (Borthakur et al. 1985; Borthakur and Johnston 1987).

In this paper, the sequence and genetic organization of the three closely linked genes pss $C$, pssD, and pssE of $R$. leguminosarum bv. trifolii TA1 is reported. In addition, in the work reported herein, the exo133::Tn5 (pssD133) mutant of TA1, which does not produce detectable amounts of acidic EPS and induces the non-nitrogen-fixing nodules on clover, was microscopically characterized.

Previously, three genes, designated $\operatorname{prs} D$, prsE (protein secretion), and orf3, were identified on the 5.26-kb PstI-BglII fragment adjacent to the exol33 mutation in cosmid pARF136 
carrying genomic DNA of $R$. leguminosarum bv. trifolii TA1 (Król and Skorupska 1997). The DNA sequence of the neighboring 4.4-kb $B g l I I-E c o$ RI fragment revealed three open reading frames (ORFs) that read toward the $B g l$ II site and were identified as $p s s C$, pssD, and pssE (Fig. 1). The Tn5 insertion in the exol33 mutant deficient in EPS synthesis was located in the middle of the pss $D$ coding region (position 1777 to $1778 \mathrm{bp}$ ). Recently, nearly identical genes of the R. leguminosarum bv. trifolii strain 5599 (van Workum et al. 1997) and R. leguminosarum bv. viciae (J. A. Downie, Norwich; EMBL accession no. Y12758) were identified. Whereas the pssCDE genes of strain TA1 were highly homologous to pssCDE of other strains, they differed in gene lengths and gene overlaps (GenBank/EMBL accession no. AF014054). The overlapping genes indicate that expression of $p s s C$, pss $D$, and $p s s E$ could be coupled. The proteins related to PssCDE, identified by a sequence homology search, showed the greatest similarity to prokaryotic glycosyl transferases (Table 1).
Mutant-Rt133-induced, non-nitrogen-fixing, white nodules on Trifolium pratense appeared 7 to 10 days later than nodules induced by the wild-type strain TA1. This was complemented by both EPS synthesis and nodulation deficiency by cosmid pARF136 and its subclones pARF1368 and pHJ. For the further mutational and transcriptional analysis of the pssDE genes, a promoter-less lacZ-Gm ${ }^{\mathrm{r}}$ interposon (Becker et al. 1995) was cloned, in both orientations, into the single HindIII or $B g l I I$ sites of plasmid pHJ (Fig. 1; Table 2). The pssD-lacZ and $p s s E$-lacZ fusions, in both orientations, were introduced by marker exchanges into the wild-type strain TA1, resulting in the $R$. leguminosarum bv. trifolii strains TAH11A,B and TAB81A,B, respectively (Table 3). The TAH11A and TAH11B mutants with $l a c Z-\mathrm{Gm}^{\mathrm{r}}$ interposon located in the $5^{\prime}$ end of pss $D$, independently of the interposon orientation, showed decrease in the nitrogenase activity measured by the reduction of acetylene (Hardy et al. 1982), compared with the wild-type activity (Table 4). The green mass of clover infected

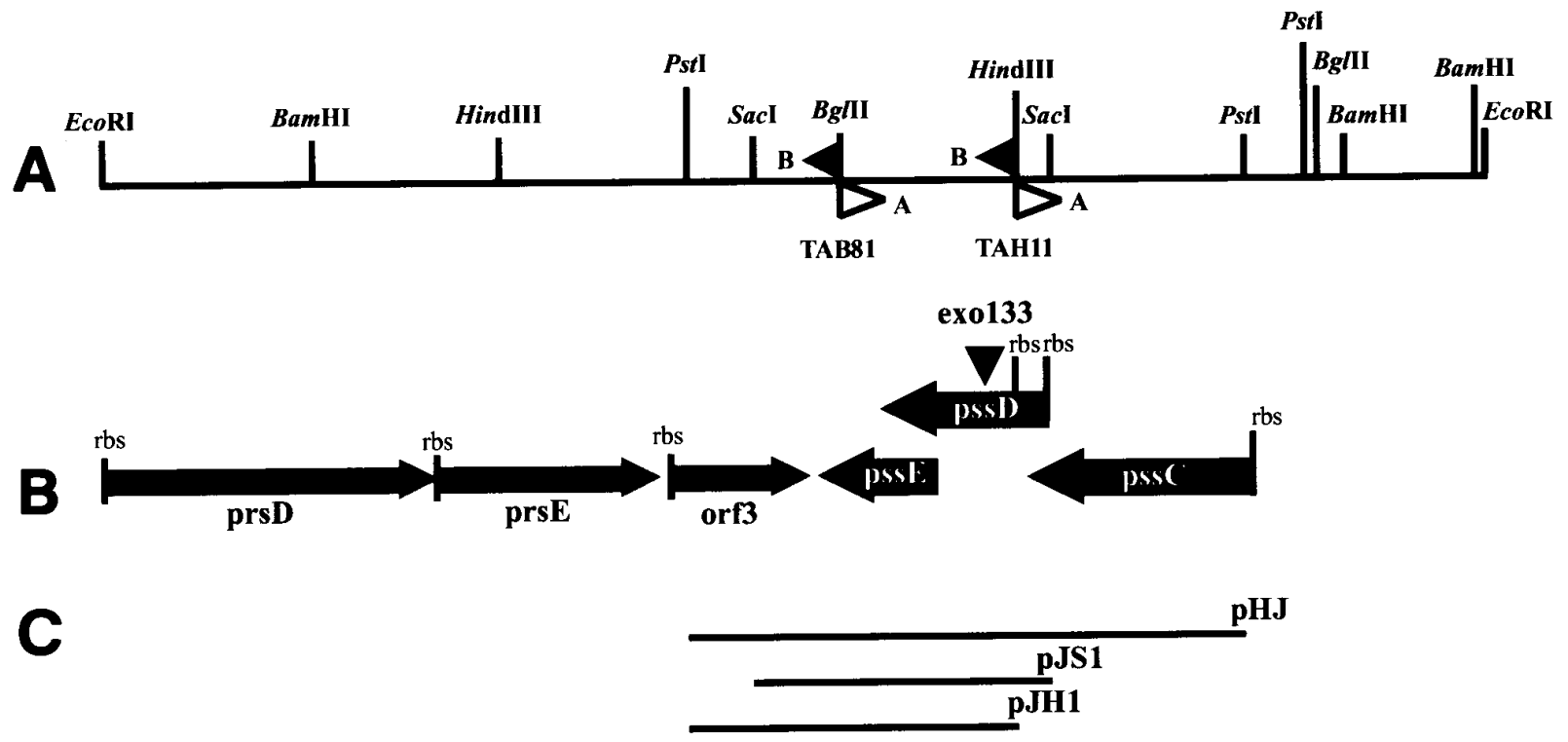

Fig. 1. Genetic organization of pss genes involved in exopolysaccharide synthesis of Rhizobium leguminosarum bv. trifolii TA1. A, Restriction map of a 7.54-kb EcoRI fragment of pARF136 insert. Insertions of the lacZ-Gm ${ }^{\mathrm{r}}$ interposon, shown as flags, indicate transcription direction of the promoterless lacZ gene. Names of Rhizobium mutants are inserted. B, The identified prsDEorf3 and pssCDE genes. Bold arrows indicate orientation of transcription, $\mathrm{rbs}=$ putative ribosome binding sites. The head arrow indicates site of Tn5 insertion in Rt133 exo mutant. C, Several restriction fragments subcloned on the plasmids with names of the constructs.

Table 1. Homologies of the proteins predicted from open reading frames (ORFs) of the pssCDE genes of Rhizobium leguminosarum bv. trifolii TA1

\begin{tabular}{|c|c|c|c|c|}
\hline $\begin{array}{l}\text { Pss } \\
\text { protein }\end{array}$ & $\begin{array}{l}\text { Predicted protein } \\
\text { (amino acids/kDa) }\end{array}$ & $\begin{array}{l}\text { Proposed function of homologous protein } \\
\text { (\% identity) }\end{array}$ & Bacteria & $\begin{array}{l}\text { Reference or EMBL } \\
\text { accession no. }\end{array}$ \\
\hline \multirow[t]{3}{*}{ PssC } & $384 / 43.5$ & PssC glycosyl transferase $(91 \%)$ & R. leguminosarum bv. trifolii 5599 & van Workum et al. 1997 \\
\hline & & PssC glycosyl transferase $(91 \%)$ & R. leguminosarum bv. viciae & Y12758 \\
\hline & & ExoM $\beta-1,4$ glycosyl transferase $(27 \%)$ & R. meliloti & Becker et al. 1993a \\
\hline \multirow[t]{5}{*}{ PssD } & $280 / 31.1$ & PssD glycosyl transferase $(87 \%)$ & R. leguminosarum bv. viciae & Y12758 \\
\hline & & PssD glycosyl transferase $(86 \%)$ & R. leguminosarum bv. trifolii 5599 & van Workum et al. 1997 \\
\hline & & Cps14F enhancer glycosyl transferase activity $(26 \%)$ & Streptococcus pneumoniae & Kolkman et al. 1997 \\
\hline & & SpsK glycosyl transferase $(30 \%)$ & Sphingomonas S88 & Yamazaki et al. 1996 \\
\hline & & EpsE glycosyl transferase (29\%) & Lactococcus lactis & van Kranenburg et al. 1997 \\
\hline \multirow[t]{5}{*}{ PssE } & $195 / 21.3$ & PssE glycosyl transferase $(90 \%)$ & R. leguminosarum bv. trifolii 5599 & van Workum et al. 1997 \\
\hline & & PssE glycosyl transferase $(90 \%)$ & R. leguminosarum bv. viciae & Y12758 \\
\hline & & EpsF glycosyl transferase $(36 \%)$ & Lactococcus lactis & van Kranenburg et al. 1997 \\
\hline & & Cps14G $\beta-1,4$ galactosyl transferase $(37 \%)$ & Streptococcus pneumoniae & Kolkman et al. 1997 \\
\hline & & SpsK glycosyl transferase $(28 \%)$ & Sphingomonas S88 & Yamazaki et al. 1996 \\
\hline
\end{tabular}


with these mutants differed insignificantly from the clover inoculated with the wild-type TA1 strain. The EPS production was $25 \%$ higher than the wild-type level when the cassette was in the sense orientation and about $20 \%$ lower when interposon was in the antisense orientation (Table 4). The $\beta$ galactosidase activity in the mutant TAH11B in the sense orientation of lacZ-Gm ${ }^{\mathrm{r}}$ was 4.8 -fold higher than in the antisense orientation (167.2 and 34.8 Miller units, respectively), indicating the presence of the promoter upstream of HindIII site. The pJH1 plasmid, which is HindIII-PstI subclone of pHJ (Fig. 1) cloned in an opposite orientation to the lac $Z$ promoter of the vector, did not complement the exol33 mutation in pss $D$. On the other hand, pJS1 plasmid containing the SacI fragment of $\mathrm{pHJ}$ cloned in both orientations complemented this mutation. These data indicated that promoter of $p s s D$ is located between SacI and HindIII sites, at the $5^{\prime}$ end of the gene. The EPS production in the mutants with the interposon inserted in HindIII site (Table 4) indicated that the ORF of the pss $D$ gene could start from the alternative ATG codon located downstream (59 bp) of the HindIII site. The AGGAGA ribosome binding site was identified 9 bp upstream of the second ATG start codon of $p s s D$ in accordance with data described by van Workum et al. (1997).

The $l a c Z-\mathrm{Gm}^{\mathrm{r}}$ insertion at pssE did not significantly affect the EPS synthesis and symbiotic phenotype of TAB81A and TAB81B mutants (Table 4). These results indicated that PssE may be not required for EPS production or that the mutation at the $3^{\prime}$ end of pssE did not affect the activity of this protein. The $\beta$-galactosidase activity of the pssE-lacZ fusion constructed in the direction of transcription was twofold higher than in the opposite direction (52.8 and 26.9 Miller units, respectively), indicating that the $p s s D E$ genes are under the same promoter.

To study in more detail the symbiotic defect revealed by pssD133 mutation, the clover was inoculated with rhizobia, root nodules processed for light and electron microscopy as described earlier (Łotocka et al. 1997). In the nodules induced

Table 4. Exopolysaccharide (EPS) production and symbiotic properties of Rhizobium leguminosarum bv. trifolii derivatives ${ }^{\mathrm{a}}$

\begin{tabular}{lcccccc}
\hline Strain & Mutation & $\begin{array}{c}\text { Total EPS } \\
(\boldsymbol{\mu g} / \mathbf{m l})\end{array}$ & $\begin{array}{c}\text { Nodule/ } \\
\text { plant (no.) }\end{array}$ & $\begin{array}{c}\text { Green wet } \\
\text { mass/plant } \\
(\mathbf{m g})\end{array}$ & $\begin{array}{c}\text { Acetylene } \\
\text { reduction } \\
\text { (nM ethy- } \\
\text { lene/h/ } \\
\text { plant) }\end{array}$ \\
\hline TA1 & Wild type & $527 \pm 86$ & $12.3 \pm 4.5$ & $76.8 \pm 9$ & $74.7 \pm 16$ \\
Rt133 & pssD::Tn5 & 0 & $4.6 \pm 1$ & $40.3 \pm 5$ & 0 \\
TAH11A & pssD-lacZ & $426 \pm 27$ & $16.5 \pm 4.6$ & $60.8 \pm 7.7$ & $34.0 \pm 7$ \\
TAH11B & pssD-lacZ & $657 \pm 93$ & $10.5 \pm 2.5$ & $66.4 \pm 8$ & $54.2 \pm 10$ \\
TAB81A & pssE-lacZ & $465 \pm 43$ & $11.9 \pm 1.8$ & $54.6 \pm 6.5$ & $61.8 \pm 15$ \\
TAB81B & pssE-lacZ & $586 \pm 48$ & $9.4 \pm 0.5$ & $60.0 \pm 8.2$ & $47.8 \pm 11$ \\
\hline
\end{tabular}

${ }^{a}$ Symbiotic properties of rhizobia were measured 28 days after inoculation. Values given are averages of at least four independent experiments with 20 plants for each treatment.

${ }^{\mathrm{b}}$ Amount of EPS is expressed as glucose equivalents (Loewus 1952).

Table 2. Plasmids and phages used

\begin{tabular}{|c|c|c|}
\hline Plasmid/phage & Relevant characteristics & Reference \\
\hline pRK7813 & IncP, $m o b, \mathrm{Tra}^{-}$cosmid vector, $\mathrm{Tc}^{\mathrm{r}}$ & Stanley et al. 1987 \\
\hline pH78 & pRK7813 carrying MCS without HindIII site & This work \\
\hline pSUP202 & pBR325 derivative, $m o b, \mathrm{Cm}^{\mathrm{r}} \mathrm{Tc}^{\mathrm{r}} \mathrm{Ap}^{\mathrm{r}}$ & Simon et al. 1983 \\
\hline pPH1JI & $\mathrm{IncP}, \mathrm{Tra}^{+}, \mathrm{Gm}^{\mathrm{r}} \mathrm{Sp}^{\mathrm{r}}$ & Beringer et al.1978 \\
\hline pHI5 & pPH1JI::Tn5, $\mathrm{Tra}^{+}$deleted derivative, $\mathrm{Km}^{\mathrm{r}} \mathrm{Gm}^{\mathrm{s}} \mathrm{Sp}^{\mathrm{s}}$ & This work \\
\hline pBBR1MCS-3 & $m o b, \mathrm{Tc}^{\mathrm{r}}$ cloning vector & Kovach et al. 1995 \\
\hline pBBR1MCS-5 & $m o b, \mathrm{Gm}^{\mathrm{r}}$ cloning vector & Kovach et al. 1995 \\
\hline pARF136 & pLAFR3 with 9-kb insert of TA1 compl ementing exo133 & Skorupska et al. 1991 \\
\hline pARF1368 & pRK7813 with 5.6-kb BamHI fragment of pARF136 complementing exol33 & Skorupska et al. 1991 \\
\hline pAB2001 & Promoterless $l a c Z-\mathrm{Gm}^{\mathrm{r}}$ interposon & Becker et al. 1995 \\
\hline $\mathrm{pHJ}$ & pH78 with a 3,036-bp PstI fragment of pARF1368 & This work \\
\hline pJH1 & pBBR1MCS-5 with a 1,796-bp HindIII-PstI fragment of pHJ & This work \\
\hline pJS1 & pBBR1MCS-3 with a 1,477-bp SacI fragment of $\mathrm{pHJ}$ & This work \\
\hline pHJH1 & pHJ derivative with $l a c Z-\mathrm{Gm}^{\mathrm{r}}$ interposon in HindIII site & This work \\
\hline pHJH2 & pHJ with $l a c Z-\mathrm{Gm}^{\mathrm{r}}$ in opposite direction as in $\mathrm{pHJH} 1$ & This work \\
\hline pSu11 & pSUP202 with insert from pHJH1 in PstI site of vector & This work \\
\hline pSu27 & pSUP202 with insert from $\mathrm{pHJH} 2$ in PstI site of vector & This work \\
\hline pJB4 & $\mathrm{pHJ}$ derivative with $l a c Z-\mathrm{Gm}^{\mathrm{r}}$ interposon in $B g l \mathrm{II}$ site & This work \\
\hline pJB8 & $\mathrm{pHJ}$ with $l a c Z-\mathrm{Gm}^{\mathrm{r}}$ in opposite direction as in pJB4 & This work \\
\hline M13mp & Sequencing vector & Sambrook et al. 1989 \\
\hline
\end{tabular}

Table 3. Bacterial strains used

\begin{tabular}{|c|c|c|}
\hline Strain & Relevant characteristics & Reference \\
\hline \multicolumn{3}{|c|}{ Rhizobium leguminosarum bv. trifolii } \\
\hline TA1 & Wild type, str rif & M. Djordjevic \\
\hline Rt133 & TA1, pssD133::Tn5 (exo133) & Król and Skorupska 1997 \\
\hline TAH11A, B & $\begin{array}{l}\text { TA1, lacZ-Gm } \mathrm{r} \text {, cassette inserted in HindIII site of pssD in the opposite direction } \\
\text { (A) and in the direction (B) of transcription }\end{array}$ & This work \\
\hline TAB81A, B & $\begin{array}{l}\text { TA1, lacZ-Gm }{ }^{\mathrm{r}} \text { cassette inserted in the BglII site of pss } E \text { in the opposite direction } \\
\text { (A) and in the direction (B) of transcription }\end{array}$ & This work \\
\hline \multicolumn{3}{|c|}{ 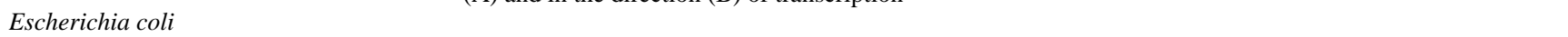 } \\
\hline JM101 & supE thi $\Delta$ (lac-proAB) $\mathrm{F}^{\prime}\left[\right.$ traD36 proAB $B^{+}$lac $I^{q}$ lacZ $\left.\Delta \mathrm{M} 15\right]$ & Sambrook et al. 1989 \\
\hline DH5 $\alpha$ & supE44 $\Delta$ lacU169 ( $\$ 80$ lacZAM15) hsdR17 recA1 endA1 gyrA96 thi-1 relA1 & Sambrook et al. 1989 \\
\hline
\end{tabular}


by the Rt133 mutant, except for the meristematic zone, none of the developmental zone typical for cylindrical nodules was observed (Vasse et al. 1990) (Fig. 2A). Immediately below the meristem, a very narrow zone of cells, much larger than the meristematic ones, and rare, very large, infection threads were observed. Even though the enlarged threads have been found mainly at the intercellular spaces, they also penetrated the plant cells and then the major part of the plant cell was filled by the infection threads. The thread-containing cells were poorly vacuolated, without flattened and parietally located amyloplasts characteristic for the bacteroidal tissue. Close to the infection threads, large clusters of the bacteria were seen (Fig. 2B). The zone, which contained the infection threads, was always very narrow in the nodule induced by the Rt133 mutant. Basipetally to that zone, there was a large area of uniform parenchyma with vacuolated cells containing numerous, round amyloplasts with starch grains (Fig. 2A). The parenchyma adjoined directly to the nodule endodermis, and in the infection zone the endodermis was separated from the atypical bacteroidal cells with a thin layer of uninfected, small cells of inner cortex. The parenchyma zone has no counterpart in the wild-type nodule, in which that space was occupied by the bacteroidal tissue and the inner cortex.

The infection threads were tightly packed with bacteria and the thread matrix was compressed into the narrow film between bacteria (Fig. 3A-C). The thread wall was not uniformly fine-fibrillar, as in the wild-type nodules, and clear, osmiophilic, discontinuous layers were observed in the thread

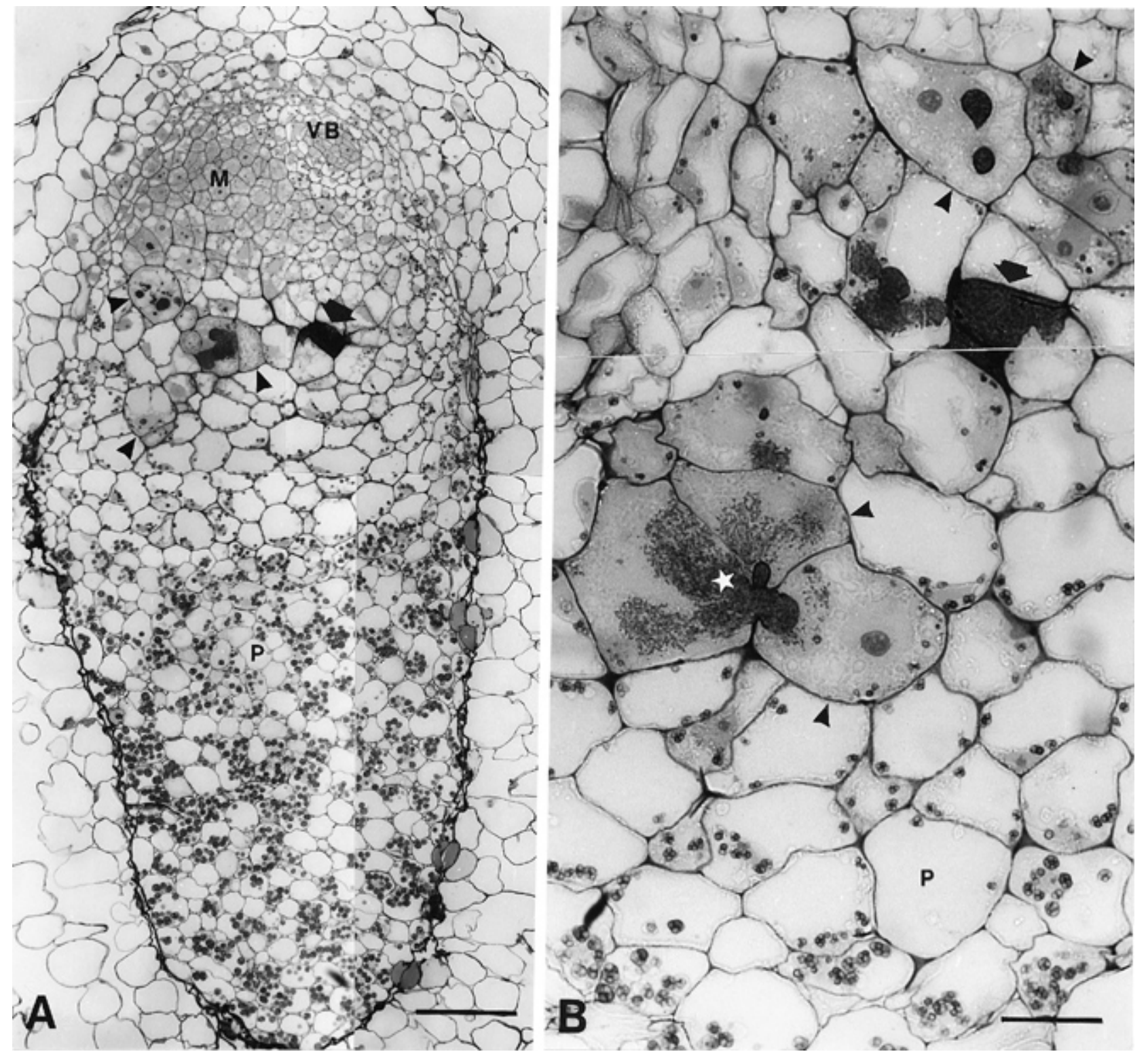

Fig. 2. Semithin section of 4-week-old clover root nodule induced by the Rhizobium leguminosarum bv. trifolii Rt133 Exo- mutant. A and $\mathbf{B}$, Nodule anatomy as seen on longitudinal section: $\mathrm{M}=$ meristematic zone; $\mathrm{VB}=$ vascular bundle; $\mathrm{P}=$ parenchyma; thick arrow $=$ infection thread in enlarged intercellular space; arrowheads $=$ cells penetrated with infection threads; white asterisk $=$ clusters of bacteria after releasing from the infection threads. Bar $=$ (A) 100 and (B) $32.60 \mu \mathrm{m}$. 

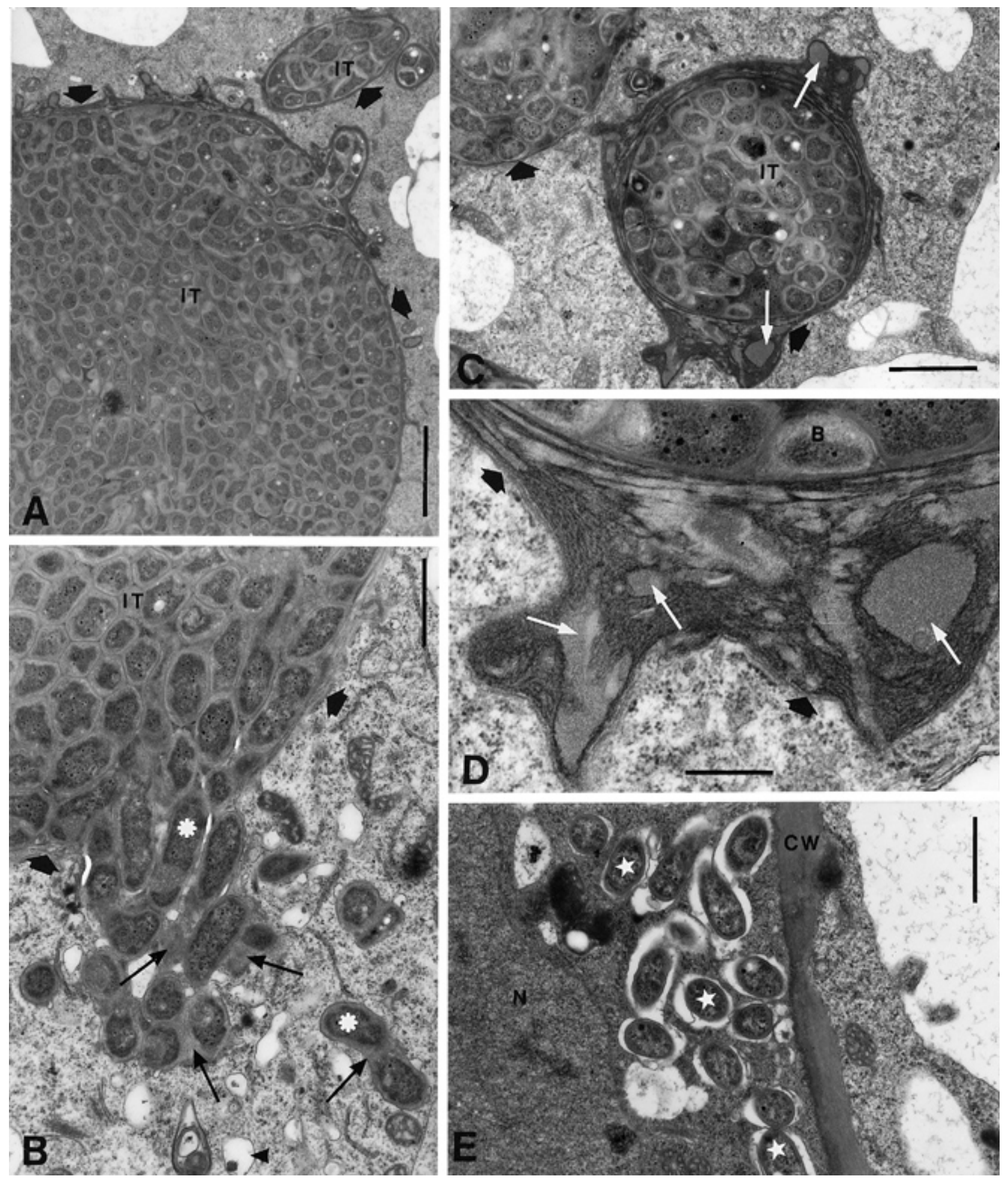

Fig. 3. Ultrastructure of infection threads in 4-week-old clover nodule induced by Rhizobium leguminosarum bv. trifolii Rt133. A, Large infection thread inside a host cell. Location of cells shown here was submeristematic. B, An area suggesting breakage of infection thread wall integrity and releasing of bacteria from infection thread into the cytoplasm: IT = infection thread; thick arrows = thread wall; arrows = thread matrix; arrowhead = vesicle with osmiophilic content; white rosettes $=$ bacteria. $\mathbf{C}$ and $\mathbf{D}$, Ultrastructure of infection thread wall: $\mathbf{B}=$ bacteria; thick arrows $=$ thread wall; white arrows $=$ homogenous inserts between osmiophilic layers of thread wall material. E, Symbiosomes in host cell: $\mathrm{CW}=$ cell wall; $\mathrm{N}=$ cell nucleus; asterisks = bacteroids. Bars $=$ (A) 3.15, (B) 1.25, (C) 1.65, (D) 0.39, and (E) $1.24 \mu \mathrm{m}$. 
walls of Rt133 nodules (Fig. 3C-D). Between the layers, homogenous and less osmiophilic material was inserted. In the cytoplasm surrounding the infection threads, large vesicles with osmiophilic content were always seen (Fig 3B). The infection thread walls with abnormal morphology and the vesicles containing the deposited material can presumably be the result of an induced plant defense response elicited by defective nodulation of the Rt133 mutant. The typical bacteria release from unwalled infection threads was not observed. Instead, it was often observed that the bacteria got out of the infection threads through the thread-wall discontinuity (mechanical breach or enzymatic digestion?) (Fig. 3B). After releasing, the bacteria were surrounded by thread matrix, but symbiosomes were observed very rarely, assuming a defect in the endocytosis process (Fig. 3E). At the ultrastructural level, the nodules induced by the Rt133 mutant that contained the enlarged infection threads with abnormal walls and densely packed bacteria resembled the nodules induced after long delay by $R$. meliloti 0540 carrying the mutation in the exoY gene (Niehaus et al. 1993). The difference between them was the way the bacteria released from the infection thread and the absence of the numerous symbiosomes into the host cytoplasm in the nodules induced by Rt133.

The conclusion that the pss CDE genes of R. leguminosarum bv. trifolii strain TA1, otherwise the same genes of strain 5599 described by van Workum et al. (1997), are significantly overlapping would suggest the coupled translation. This difference could be explained by the different geographical origin of both strains. The TA1 strain is an Australian strain described as defective in nodulation of Trifolium subterraneum cv. Woogenellup in unfavorable environmental conditions (Lewis-Henderson and Djordjevic 1991). The RBL5599 strain is a European strain with marked pSym5 introduced into the cured pSym $R$. leguminosarum bv. trifolii LPR5 strain (van Workum et al. 1997).

The $p s s D$ gene, in the longest possible ORF, overlaps pss $C$ and $p s s E$ genes, but the genetic complementation of the exol33 mutation and production of EPS in $R$. leguminosarum bv. trifolii mutated in the N-terminal part of the PSsD protein indicates the possibility that PssD starts from the alternative ATG codon. The Tn5 insertion in the central region of $p s s D$ totally abolished the EPS production and the $R$. leguminosarum bv. trifolii Rt133 mutant induced non-nitrogen-fixing nodules on clover. From these results, one could conclude that pss $D$ gene encoding for glycosyl transferase is required for biosynthesis of EPS. The pssD::Tn5 (exol11) mutant described by van Workum et al. (1997) is located 43 bp upstream of pssD133 and displayed similar phenotype in respect of EPS production and symbiosis with clover. Transcriptional fusion $p s s D$-lac $Z$ and the complementation data with the restriction fragments containing the deleted $5^{\prime}$ end of $p s s D$ indicated the presence of the promoter for pss $D E$ genes upstream of the HindIII site. The pssD gene of TA1 in the shorter form is $162 \mathrm{bp}$ longer at the $3^{\prime}$ end than the pssD of strain 5599 and significantly overlaps the pssE. The level of $\beta$-galactosidase activity in the transcriptional fusions of pssE-lacZ indicated the presence of the common promoter for pss $D E$ genes. The respective homogenotes of $R$. leguminosarum bv. trifolii did not reveal symbiotic defects, and EPS production is comparable to the wild-type level. Therefore, the putative function of PssE as glycosyl transferase in EPS biosynthesis can be pro- posed only based on the sequence homology to known proteins. The latest experimental data showed the common action of PssDE as glucuronosyl transferase in acidic EPS biosynthesis of R. leguminosarum bv. trifolii 5599 (Pollock et al. 1998).

\section{ACKNOWLEDGMENTS}

We thank A. Pühler for sending us the vectors with interposon lacZ$\mathrm{Gm}^{\mathrm{r}}$ and M. E. Kovach for $\mathrm{pBBR}$ vectors. We also thank Maria Małek for excellent technical assistance. This work was supported by the Polish Committee for Scientific Research grant no. 6 PO4B 01410.

\section{LITERATURE CITED}

Becker, A., Kleickmann, A., Keller, M., Arnold, W., and Pühler, A. 1993a. Identification and analysis of the Rhizobium meliloti exoAMONP genes involved in exopolysaccharide biosynthesis and mapping of promoters located on the exoHKLAMONP fragment. Mol. Gen. Genet. 241:367-379.

Becker, A., Kleickmann, A., Küster, H., Keller, M., Arnold, W. and Pühler, A. 1993b. Analysis of the Rhizobium meliloti genes exoU, exo $\mathrm{V}$, exo $\mathrm{W}$, exo $\mathrm{T}$, and exoI involved in exopolysaccharide biosynthesis and nodule invasion: exoU and exoW probably encode glucosyltransferases. Mol. Plant-Microbe Interact. 6:735-744.

Becker, A., Rüberg, S., Küster, H., Roxlau, A. A., Keller, M., Ivashina, T., Cheng, H.-P., Walker, G. C., and Pühler, A. 1997. The 32-kilobase exp gene cluster of Rhizobium meliloti directing the biosynthesis of galactoglucan: Genetic organization and properties of the encoded gene products. J. Bacteriol. 179:1375-1384.

Becker, A., Schmidt, M., Jäger, W., and Pühler, A. 1995. New gentamycin resistance and lacZ promoter-probe cassettes suitable for insertion mutagenesis and generation of transcriptional fusions. Gene 162:37-39.

Beringer, J. E., Beynon, J. L., Buchanan-Wollaston, A. V., Hirsch, P. R., and Johnston, A. W. B. 1978. Introduction of the drug resistance transposon Tn5 into Rhizobium. Nature 276:633-634.

Białek, U., Skorupska, A., Yang, W.-C., Bisseling, T., and Van Lammeren, A. A. M. 1995. Disturbed gene expression and bacterial development in Trifolium pratense root nodules induced by a $\operatorname{Tn} 5 \mathrm{mu}-$ tant of Rhizobium leguminosarum bv. trifolii defective in exopolysaccharide synthesis. Planta 197:184-192.

Borthakur, D., Barber, C. E., Lamb, J. W., Daniels, M. J., Downie, J. A., and Johnston, A. W. B. 1986. A mutation that blocks exopolysaccharide synthesis prevents nodulation of peas by Rhizobium leguminosarum but not of beans by Rhizobium phaseoli and is corrected by cloned DNA from Rhizobium or the phytopathogen Xanthomonas. Mol. Gen. Genet. 203:320-323.

Borthakur, D., Barker, R. F., Latchford, J. W., Rossen, L., and Johnston, A. W. B. 1988. Analysis of pss genes in Rhizobium leguminosarum required for exopolysaccharide synthesis and nodulation of peas: Their primary structure and their interaction with $p s i$ and other nodulation genes. Mol. Gen. Genet. 213:155-162.

Borthakur, D., Downie, J. A., Johnston, A. W. B., and Lamb, J. W. 1985. psi, a plasmid-linked Rhizobium phaseoli gene that inhibits exopolysaccharide production and which is required for symbiotic nitrogen fixation. Mol. Gen. Genet. 200:278-282.

Borthakur, D., and Johnston, A. W. B. 1987. Sequence of psi, a gene on the symbiotic plasmid of Rhizobium phaseoli which inhibits exopolysaccharide synthesis and nodulation and demonstration that its transcription is inhibited by $p s r$, another gene on the symbiotic plasmid. Mol. Gen. Genet. 207:149-154.

Buendia, A. M., Enenkel, B., Köplin, R., Niehaus, K., Arnold, W., and Pühler, A. 1991. The Rhizobium meliloti exoZ/exoB fragment of megaplasmid 2: ExoB functions as a UDP-glucose 4-epimerase and ExoZ shows homology to NodX of Rhizobium leguminosarum biovar viciae strain TOM. Mol. Microbiol. 5:1519-1530.

Chen, H., Batley, M., Redmond, J., and Rolfe, B. G. 1985. Alteration of the effective nodulation properties of a fast-growing broad host range Rhizobium due to changes in exopolysaccharide synthesis. J. Plant Physiol. 120:331-349.

Deryło, M., Skorupska, A., Bednara, J., and Lorkiewicz, Z. 1986. Rhizobium trifolii mutants deficient in exopolysaccharide production. Physiol. Plant. 66:699-704. 
Diebold, R., and Noel, K. D. 1989. Rhizobium leguminosarum exopolysaccharide mutants: Biochemical and genetic analyses and symbiotic behaviour on three hosts. J. Bacteriol. 171:4821-4830.

Glucksmann, M. A., Reuber, T. L., and Walker, G. C. 1993a. Family of glucosyl transferases needed for the synthesis of succinoglycan by Rhizobium meliloti. J. Bacteriol. 175:7033-7044.

Glucksmann, M. A., Reuber, T. L., and Walker, G. C. 1993b. Genes needed for the modification, polymerization, export, and processing of succinoglycan by Rhizobium meliloti: A model for succinoglycan biosynthesis. J. Bacteriol. 175:7045-7055.

Hardy, R. W., Holsten, R. D., Jackson, E. K., and Burns, C. 1982. The $\mathrm{C}_{2} \mathrm{H}_{2}-\mathrm{C}_{2} \mathrm{H}_{4}$ assay for $\mathrm{N}_{2}$ fixation. Laboratory and field evolution. Plant Physiol. 43:1185-1210.

Ivashina, T. V., Khmelnitsky, M. I., Shlyapnikov, M. G., Kanapin, A. A., and Ksenzenko, V. N. 1994. The pss4 gene from Rhizobium leguminosarum bv. viciae VF39: Cloning, sequence and the possible role in polysaccharide production and nodule formation. Gene 150:111-116.

Kolkman, M. A. B., van der Zeijst, B. A. M. and Nuijten, P. J. M. 1997. Functional analysis of glycosyltransferases encoded by the capsular polysaccharide biosynthesis locus of Streptococcus pneumoniae serotype 14. J. Biol. Chem. 272:19502-19508.

Kovach, M. E., Elzer, P. H., Hill, D. S., Robertson, G. T., Farris, M. A., Roop, R. M., II, and Peterson, K. M. 1995. Four new derivatives of the broad-host-range cloning vector pBBR1MCS, carrying different antibiotic-resistance cassettes. Gene 166:175-176.

Król, J., and Skorupska, A. 1997. Identification of genes in Rhizobium leguminosarum bv. trifolii whose products are homologous to a family of ATP-binding proteins. Microbiology 143:1389-1394.

Leigh, J. A., and Walker, G. C. 1994. Exopolysaccharides of Rhizobium: Synthesis, regulation and symbiotic function. Trends Genet. 10:63-67.

Lewis-Henderson, W. R., and Djordjevic, M. A. 1991. A cultivarspecific interaction between Rhizobium leguminosarum bv. trifolii and subterranean clover is conditioned by nodM, other bacterial cultivar specificity genes, and a single recessive host gene. J. Bacteriol. 173: 2791-2799.

Loewus, F. A. 1952. Improvement in the anthrone method for determination of carbohydrates. Anal. Chem. 24: 219.

Łotocka, B., Kopcińska, J. and Golinowski, W. 1997. Morphogenesis of root nodules in white clover. I. Effective root nodules induced by the wild type Rhizobium leguminosarum biovar trifolii. Acta Soc. Bot. Polon. 66:273-292

Müller, P., Keller, M., Weng, W. M., Quandt, J., Arnold, W., and Pühler, A. 1993. Genetic analysis of the Rhizobium meliloti exoYFQ operon: ExoY is homologous to sugar transferases and ExoQ represents a transmembrane protein. Mol. Plant-Microbe Interact. 6:55-65.

Niehaus, K., Kapp, D., and Pühler, A. 1993. Plant defence and delayed infection of alfalfa pseudonodules induced by an exopolysaccharide (EPSI)-deficient Rhizobium meliloti mutant. Planta 190:415-425.

Noel, K. D. 1992. Rhizobial polysaccharides required in symbioses with legumes. Pages 341-357 in: Molecular Signals in Plant-Microbe Communications. D. P. S. Verma, ed. CRC Press, Boca Raton, FL.

Pollock, T. J., van Workum, W. A. T., Thorne, L., Mikolajczak, M. J.,
Yamazaki, M. , Kijne, J. W., and Armentrout, R. W. 1998. Assignment of biochemical functions to glycosyl transferase genes essential for biosynthesis of exopolysaccharides in Sphingomonas strain S88 and Rhizobium leguminosarum. J. Bacteriol. 180:586-593.

Reuber, T. L., and Walker, G. C. 1993. Biosynthesis of succinoglycan, a symbiotically important exopolysaccharide of Rhizobium meliloti. Cell 74:269-280.

Rolfe, B. G., Carlson, R. W., Ridge, R. W., Dazzo, F. B., Mateos, P. F., and Pankhurst, C. E. 1996. Defective infection and nodulation of clovers by exopolysaccharide mutants of Rhizobium leguminosarum bv. trifolii. Aust. J. Plant Physiol. 23;285-303.

Sambrook, J., Fritsch, E. F., and Maniatis, T. A. 1989. Molecular Cloning: A Laboratory Manual. 2nd ed. Cold Spring Harbor Laboratory, Cold Spring Harbor, NY.

Sanchez-Andujar, B., Coronado, C., Philip-Hollingsworth, S., Dazzo, F. B., and Palomares, A. J. 1997. Structure and role in symbiosis of the exoB gene of Rhizobium leguminosarum bv. trifolii. Mol. Gen. Genet. 255:131-140.

Simon, R., Priefer, U., and Pühler, A. 1983. A broad host range mobilization system for in vivo genetic engineering: Transposon mutagenesis in gram-negative bacteria. Bio/Technology 1:784-791.

Skorupska, A., Białek, U., Urbanik-Sypniewska, T., and Van Lammeren, A. 1995. Two types of nodules induced on Trifolium pratense by mutants of Rhizobium leguminosarum bv. trifolii deficient in exopolysaccharide production. J. Plant Physiol. 147:93-100.

Skorupska, A., Deryło, M., and Golinowski, W. 1991. The region for exopolysaccharide synthesis on Rhizobium leguminosarum bv. trifolii is located on the non-symbiotic plasmid. Acta Biochim. Polon. 38: 423-435.

Stanley, J., Dowling, D. N., Stucker, M., and Broughton, W. J. 1987. Screening costramid libraries for chromosomal genes: An alternative interspecific hybridization method. FEMS Microbiol. Lett. 48:25-30.

van Kranenburg, R., Marugg, J. D., van Swam I. I., Willem, N. J., and de Vos, W. M. 1997. Molecular characterization of the plasmid-encoded eps gene cluster essential for exopolysaccharide biosynthesis in Lactococcus lactis. Mol. Microbiol. 24:387-397.

van Workum, W. A. T., Canter Cremers, H. C. J., Wijfjes, A. H. M., van der Kolk, C., Wijffelman C. A., and Kijne, J. W. 1997. Cloning and characterization of four genes of Rhizobium leguminosarum bv. trifolii involved in exopolysaccharide production and nodulation. Mol. Plant-Microbe Interact. 10:290-301.

van Workum, W. A. T., van Brussel, A. A. N., Tak, T., Wijffelman, C. A., and Kijne, J. W. 1995. Ethylene prevents nodulation of Vicia sativa ssp. nigra by exopolysaccharide-deficient mutants of Rhizobium leguminosarum bv. viciae. Mol. Plant-Microbe Interact. 8:278-285.

Vasse, J., de Billy, F., Camut, S., and Truchet, G. 1990. Correlation between ultrastructural differentiation of bacteroids and nitrogen fixation in alfalfa nodules. J. Bacteriol. 172:4295-4306.

Yamazaki, M., Thorne, L., Mikolajczak M., Armentrout, R. W., and Pollock T. J. 1996. Linkage of genes essential for synthesis of a polysaccharide capsule in Sphingomonas strain S88. J. Bacteriol. 178: 2676-2687. 